\title{
Some state records and deletions of Asian Cruciferae
}

\author{
D. A. German \\ South-Siberian Botanical Garden, Altai State University, Lenin Ave., 61, Barnaul, 656049, Russia \\ E-mail: oreoloma@rambler.ru; ORCID iD: 0000-0001-7951-1644
}

\begin{abstract}
Keywords: Brassicaceae, Cryptospora, distribution, Dontostemon, Erysimum, Guenthera, Himalayas, Middle and SW Asia, Neotorularia, Noccaea, Sterigmostemum.

Summary. Based on revision of various herbaria collections, Cruciferae (Brassicaceae) species lists of certain Asian countries are updated. These include first records of the following species/subspecies from relevant states mentioned in parentheses: Cryptospora trichocarpa (Afghanistan), Guenthera persica subsp. takhtajanii, comb. nova (Turkey, Iran, Syria), Neotorularia brevipes (Tajikistan), Noccaea apterocarpa (Turkmenistan), N. campylophylla s. 1. (Iraq). The cases of non-confirmed occurrence of other species in relevant countries are also revealed: Camelina hispida (Uzbekistan), Dontostemon pinnatifidus (Nepal), Erysimum crassipes, Noccaea trinervia and Sterigmostemum acanthocarpum (Turkmenistan), and Noccaea kurdica (Iraq). Additional comments on presence of certain species in the flora of Georgia, Iran, Kyrgyzstan, and Russia are provided.
\end{abstract}

\section{К видовому составу крестоцветных (Cruciferae) некоторых стран Азии}

\author{
Д. А. Герман \\ Южно-Сибирский ботанический сад, Алтайский государственный университет, \\ просп. Ленина, 61, г. Барнаул, 656049, Россия
}

\begin{abstract}
Ключевые слова: Гималаи, распространение, Средняя и Юго-Западная Азия, Brassicaceae, Cryptospora, Dontostemon, Erysimum, Guenthera, Neotorularia, Noccaea, Sterigmostemum.

Аннотация. По результатам ревизии ряда гербарных коллекций приводится уточнение видового состава крестоцветных (Cruciferae, или Brassicaceae) некоторых стран Азии. Cryptospora trichocarpa впервые отмечается во флоре Афганистана, Guenthera persica subsp. takhtajanii, comb. nova - Турции, Ирана и Сирии, Neotorularia brevipes - Таджикистана, Noccaea apterocarpa - Туркменистана и N. campylophylla s. 1. - Ирака. В то же время, произрастание Camelina hispida в Узбекистане, Dontostemon pinnatifidus - в Непале, Erysimum crassipes, Noccaea trinervia и Sterigmostemum acanthocarpum - в Туркменистане, а также Noccaea kurdica - в Ираке не получает подтверждения. Дополнительно кратко прокомментировано нахождение отдельных видов в Грузии, Иране, Кыргызстане и России.
\end{abstract}

In the course of revising the Cruciferae (Brassicaceae) collections in various herbaria, some species previously unrecorded from certain Asian countries were found. At the same time, state reports that cannot be confirmed were also revealed. Of them, only those based on the cited specimens (or for which such specimens could be unambiguously traced) were taken into consideration. Doubt- ful mentions not supported by concrete references to the studied material scattered through the floristic literature were not treated as confirmed records and are not reviewed here.

The study is based on revision of herbarium collections BAK, BASBG, BM, BP, BRNM, BRNU, C, E, G, GAZI, GZU, HUB, JE, K, KFTA, LD, LE, LECB, MSB, MW, TBI, W, and WU. In addition, 
specimens from KUFS and partly E (Dontostemon Andrz. ex C. A. Mey.) were studied as digital images via the databases Virtual Herbaria [2021] and RBGE [2021], respectively. Finally, for Noccaea iranica Al-Shehbaz, a photo of the type (TARI) has been seen.

\section{Records}

\section{Cryptospora trichocarpa Botsch.}

Afghanistan: " $10 \mathrm{~m}$ [iles] N of Doshi, Katahgan [Baghlan] Province. 2500' alt. Stony slopes with $A r$ temisia and annuals, never cultivated. 15. 05. 1964. P. Furse 5973" (K, LE); "Badakhshan: Oestl. Seitental der Darya-e Meshad, oberhalb Kangurchi. Alt. 1300-1700 m. 22. 05. 1971. O. Anders 6639" (KUFS [KUFS002443]: http://jacq.nhm-wien.ac.at/ djatoka/jacq-viewer/viewer.html?rft_id=kufs_0024 43\&identifiers $=$ kufs 002443).

The species has hitherto been considered endemic to Tajikistan where it is only known from the southwestern part adjacent to Afghanistan (Botschantzev, 1963; Pachomova, 1974; Yunusov, 1978; Nowak, Nobis, 2020; POWO, 2021), why its finding in the latter country could well be expected. Both cited gatherings were initially determined as morphologically close $C$. falcata Kar. et Kir., but LE specimen was revised as $C$. trichocarpa by Botschantzev yet in late 1971. However, this determination apparently was not published by now. According to the updated information, natural range of the species is restricted to SW Tajikistan and NE Afghanistan and its finding elsewhere is unlikely.

Guenthera persica subsp. takhtajanii (V. I. Dorof.) D. A. German, comb. nov. $\equiv$ Erucastrum takhtajanii V. I. Dorof., 2000, Bot. Zhurn. 85, 7: 183.

Turkey: "[B6] A6 Sivas: Kangal - Gürün aras1, 18 km, Kireçli tüf, 1650 m. 10. 07. 2007. Z. Aytaç 9081" (GAZI); "[B6] A6 Sivas: Ulas - Gürün aras1, Gürün'e 58 km kala, 1565 m, 3907'43.6" K, $37^{\circ} 14^{\prime} .8^{\prime \prime} \mathrm{D}$, step, marnlı yamaçlar, 25. 07. 2008. Adil Güner 15151" (GAZI [GAZI9999000065199]); "B6 Sivas: Gürün - Kangal bei Samakurd, 1620 m, Gipshügel. 13. 07. 1982. Max Nydegger 17102" (BASBG-00173660, G); “[B6] Prov. Sivas: Gürün. On loose scrub scree. Alt. 1200 m. 19 June 1960. Stainton \& Henderson 5668" (E [E00197054]); "[B6] Sivas (Pontus). Distr. Kangal. Tecer - Gürün. Kalkmergel 36-37 km südl. Tecer. 1620 m ü. M. 27 Juni 1955. A. Huber-Morath 13106" (G); "B6 Sivas: Gürün - Sivas. 36 km s Sivas bei Samakurd, 1550 m,
Gipshügel. 11. 07. 1981. Max Nydegger 16903 \& 16877” (G); “[B6] Vil. Sivas. Strasse Sivas - Gürün. 78 km von Sivas, 1530 m. 27 Juni 1955. C. Simon" (BASBG-00173681); "[B6] Prov. Sivas: Gürün, $3500 \mathrm{ft}$. Eroded hills of calc. shale. 19 June 1954. P. H. Davis 21687” (E [E00439548], K); “[B6] Sivas, Kangal, Düşek mevkii, 39.239005 K, 37.351054 D, 1125 m, jipsli arazi, 15. 07. 2007. B. Özüdoğru” (HUB); "B6 Malatya: Straße O, Malatya 94,8, Gürün - 140; 1,0 km W Karşıyaka köyü an der Straße nach Darende, 1030 m, Schutthang. 26. 08. 1975. K. P. \& E. Buttler 20321" (MSB); "B6 Malatya: Straße O, Malatya - 91,2, Gürün - 140; 1,8 km E Karşıyaka köyü an der Straße nach Balaban (c. 12 km E Darende), 960 m, Steppe. 11. 09. 1977. K. P. Buttler 23183 \& R. von Bothmer" (MSB); "B7 Tunceli: Ovacık, Tornova üstü, Munzur Dağları, 11001450 m, 26. 07. 1979. Ș. Yildırımlı 2164" (HUB № 06501); "[B7] Prov. Tunceli: Pertek - Tunceli, 26 miles from Elaziğ, $1400 \mathrm{~m}$. Chrystalline limestone ravine. 06. 06. 1957. P. H. Davis 29116 \& I. C. Hedge" (BM [BM010750790], E [E00439547], K); "[B7 Elâzığg]: Armenia turcica, Kharput, Muradlu, in campis. 1 VI 1889. P. Sintenis 613" (LD).

Iran: "West Azerbaijan: Bazargan, northwest corner of Iran, on Turkish border, semi-desert, 2000 m, 15 July 1964. Martin L. Grant 16215" (W 196518022); "Persia, Prov. Azerbaijan occid.: In faucibus calc. 86 km WNW Marand, 1000 m. 8 VI 1971. K. H. Rechinger 41505" (W 1973-11864).

Syria: "In gramin. Ras el Ain [Ras al-Ayn]. Mai 1867. C. Hausskhecht" (BM [BM010750784], W).

The taxon was described as endemic to Armenia (Dorofeyev, 2000). POWO (2021) lists it [as Brassica elongata subsp. takhtajanii (V. I. Dorof.) D. A. German], in addition to Transcaucasia, also for Turkey referring to Dorofeyev (2012). However, in the latter publication Turkey is only mentioned in the general distribution of the species (as Erucastrum takhtajanii) and its presence in the country was not hitherto confirmed by a single cited specimen. As here reported, Guenthera elongata subsp. takhtajanii occurs in four Turkish provinces and the main part of its distribution area is situated there.

Upon studying sufficient additional material I, contrary to the viewpoint of German (2015) on possible equality of the discussed entity to Brassica elongata var. scabra O. E. Schulz, have to return to my previous (German, 2005) approach regarding the status of Erucastrum takhtajanii and treat it as a subspecies, though of Guenthera persica (Boiss. et Hohen.) D. A. German [under which, if recognized, B. elongata var. scabra should also be 
subsumed]. Unlike other taxa of this affinity such as Brassica beytepeensis Y1ld., B. brevirostrata Z. X. An, and B. elongata subsp. duralii Y1ld., which clearly represent variants of $G$. persica s. str. not deserving taxonomic recognition, E. takhtajanii possesses not only higher intensity (exhibited also by $B$. elongata var. scabra), but also a unique type of indumentum (straight and patent vs. curved upward and antrorse trichomes) which in combination with its well-defined E Anatolian - SW Transcaucasian distribution justifies a rank higher than varietal. On the other hand, rare intermediates to B. elongata var. scabra (e. g., Buttler \& Buttler № 20321, Sintenis № 613) along with overall habitual resemblance with $G$. persica s. str. prevent me from treating it as a distinct species.

Neotorularia brevipes (Kar. et Kir.) Hedge et J. Léonard

Tajikistan: "Badakhshan Autonomous Province, silted stony hill slope at the mouth of Takhta-Korum, ca. 3800 m a. s. 1.28 VII 1958. N. N. Tzvelev 878 " (LE).

Despite its relatively spacious, predominantly Turano-Dzhungarian distribution stretching latitudinally from W Kazakhstan to W Mongolia (but reaching NE Baluchistan in the south), N. brevipes is a rarely collected species, apparently due to its tiny habit and ephemeral life form. While most of (though still not numerous) gatherings originate from Kazakhstan, those from China (Xinjiang), Afghanistan and Pakistan are scarce or even single and distant from each other (Jafri, 1973; Zhou et al., 2001; German, Chen, 2009; Breckle et al., 2013; Al-Shehbaz, 2015) and sometimes mixed with other species (cf. Jafri, 1973; Zhou et al., 2001). The above first record from Tajikistan is just in line with them. It is represented by a single plant found as an admixture to the gathering of Atelanthera perpusilla Hook. f. et Thoms. among numerous specimens of the latter species stored in an envelope attached to the herbarium sheet. Therefore, despite no doubts in the specimen identity, additional gatherings of $N$. brevipes from Tajikistan are desirable to confirm the present - somewhat ephemeral - finding and exclude the possibility of any confusion.

Distribution of $N$. brevipes requires further elucidation also with regards to its occurrence in Kyrgyzstan and Turkmenistan. As far as I could check, both countries were first listed in the general distribution of the species by Zhou et al. (2001) and then this information was copied by German \& Chen (2009), Al-Shehbaz (2015), and POWO (2021). Meanwhile, no specimens have been seen in LE or elsewhere and no respective authors (Bondarenko, 1974; Nikitin, Geldikhanov, 1988; Lazkov, Sultanova, 2014) confirm presence of $N$. brevipes in any of these two countries.

Noccaea apterocarpa (Rech. f. et Aellen) AlShehbaz et Menke

Turkmenistan: "Turcomania. In m. Ludscha pr. Ashabad ca. $6800^{\mathrm{T}}$. $6 \mathrm{~V}$ 1898. D. Litwinow 594" (BAK, BP №№ 137445, 697222, BRNM, E [E00199877, E00199878], G, JE, KFTA, LE (5×), TBI, WU); "Transcaspian prov., Ashabad distr., Kopet-Dagh Mts., between the border posts Kheirabad and Chayek. 27 IV 1912. V. I. Lipsky 2330" (BRNU №№ 95266, 322601, LE (5×), LECB (2×), MW [MW0833826]); "id., ibid., 26 IV 1912. № 2249” (BAK, LE (2×)); “Turkmenia, Central Kopet-Dagh, 50 km SW Geok-Tepe. High mountainous meadows on Mt. Mesinev. 21 V 1963. I. A. Gubanov \& A. A. Mestcheryakov 367" (LE, MW [MW0833827]); “Transcaspian prov., Kopetdagh. V 1895. G. K. Minkwitz (LE); Kopetdagh, Mt. Seamasur, zone of juniper woods. 8 VI 1924. E. Czerniakowska 98” (LE); “Ak-dagh. $24 \mathrm{~V}$ [18]87. Walter" (LE); "Turkmenia, Central Kopet-Dagh, Chopan-Dagh, stony slope, ca. $2700 \mathrm{~m} \mathrm{s.} \mathrm{m.} 2$ VI 1975. N. Belyanina \& G. Proskuryakova" (MW [MW0833822, MW0833823]); "Central KopetDagh, gorge Karanki (to the west of Gaudan), stony slope, ca. 960 m s. m. 29 V 1975. N. Belyanina \& G. Proskuryakova" (MW [MW0833824, MW0833825]).

Noccaea apterocarpa is a member of $N$. trinervia (DC.) Steud. [formerly widely known as Aethionema trinervium (DC.) Boiss. or Iberidella trinervia (DC.) Boiss.] complex, "most different from typical A. trinervium" (Khosravi et al., 2009) among other taxa of this group. For quite a long time it was treated as a variety of $A$. trinervium (e. g., Hedge, 1968; Zohary et al., 1980), but nowadays is usually accepted as a distinct species (Al-Shehbaz, 2012, 2014; Fakhr Ranjberi, 2017; POWO, 2021). Since the time of its description (Rechinger, 1951) and by now it was known as endemic to KhorassanKopet Dagh floristic province of Iran; hence, its occurrence in adjacent Turkmenistan was quite predictable. Revision of herbarium material fully confirmed this expectation and, furthermore, demonstrated that all gatherings of $N$. trinervia s. 1 . from Turkmenistan (restricted exclusively to Kopet Dagh) belong to $N$. apterocarpa. Therefore, $N$. trinervia $\mathrm{s}$. str. is to be excluded from the flora of the country. Noteworthy, 
easternmost populations (from Kazakhstan, Kyrgyzstan, and Uzbekistan) are again represented by quite typical $N$. trinervia.

Noccaea campylophylla (F. K. Mey.) Al-Shehbaz s. 1.

Iraq: [Arbil]: "Helgord Range [Algurd Dagh], c. 2800-3000 m, E site of mt. slope. 1 IX 1957. Ali Al-Rawi \& [Ismail] Serhang 24755" (K); [Mosul]: "NE of Qandil, c. 2850-3100 m, on mountain side. 26 XIII 1957. Ali Al-Rawi \& Serhang 24440" (K).

These two gatherings is the only material based on which a related congener, $N$. kurdica (Hedge) AlShehbaz, has been reported for Iraq (Hedge, 1968; Hedge, Lamond, 1980, as Thlaspi kurdicum Hedge). Meyer (2006) questioned this information but, having no opportunity to check the specimens, left the problem open. A study of relevant plants revealed that they form very dense (vs. rather loose) cushions and possess profoundly veined and rigid, rosette chiefly linear to linear-oblanceolate and acute (vs. obscurely veined and softer, rosette spatulate and predominantly obtuse) leaves. Relevant characters distinguish $N$. kurdica, whos features are given in brackets, from a group of three closely related species, viz. N. campylophylla, N. pulvinata (F. K. Mey.) Al-Shehbaz, and N. iranica Al-Shehbaz, none of which was hitherto recorded from Iraq. Exact identification of the Iraqi plants is problematic for two reasons. The first is the scarcity and condition of specimens represented collectively by just three small fruiting plants with nearly all valves fallen off. The second is a closeness to each other of the mentioned three species, referred to herein as $N$. campylophylla s. 1., and lack of a clear morphological distinction among them. Formally, because of the completely exauriculate cauline leaves, the discussed specimens are assignable to $N$. iranica. However, they do not exhibit sharp leaf heteromorphy (linearfiliform rosette vs. lanceolate to narrowly so stem leaves) reported for the latter species (Mozaffarian, 1996, as Thlaspi pulvinatum Mozaff.) and discernable on its type (TARI) and often, though not always so clearly, observed in N. campylophylla. In this, the Iraqi plants are most similar to the habitually and geographically closest $N$. pulvinata, but differ from it in bigger fruits (of the size and shape characteristic to N. campylophylla) without apical notch and absence of auricles in cauline leaves. In terms of stem leaf base, the most distant from the discussed specimens are typical plants of $N$. campylophylla which demonstrate clearly auriculate and deeply sagittate leaves, but it is noteworthy that others exhibit much less developed auricles approaching in this respect $N$. pulvinata. It is a matter of further study to elucidate whether such characters as morphology of leaf base, fruit and petal size, development of valve wing and others used to distinguish the mentioned three entities of $N$. campylophylla s. 1. (Meyer, 2006; Al-Shehbaz, 2014) are species-specific [and then all three if not four species, meaning additionally the Iraqi one, should be recognized] or there is a continuum of combinations reflecting differences in ecological conditions and possibly onthogenetic stage of individual plants. Available material is quite limited which hampers making sound conclusion on this matter.

By contrast and based on the above-said, it is difficult to agree with synonymizing $N$. iranica with N. kurdica proposed by Fakhr Ranjberi (2017). Hence, presence of the latter in the flora of Iran also needs confirmation having in mind that the earlier mention for Iran by Esfandiari (1978; cited from Akhani, 2003) did not get support by subsequent studies (Meyer, 2006; Al-Shehbaz, 2014) either. Relevant gathering: "Iran, Azerbaidzan: Makou. Sarichaman to Guerkhlar. 2200-2600 m. 13 VI 1970. Termé 20188-E" (E [E00376260], JE, W 1972-01178) has been revised and cited by Meyer (2006: 221) as Vania campylophylla F. K. Mey. [s. str.] though again as N. kurdica by Fakhr Ranjberi (2017: 156). I fully agree with Meyer's identification, and revision of other collections given in the Flora of Iran is needed to clarify whether they all belong to $N$. campylophylla and $N$. iranica or true $N$. kurdica still occurs in the country. Noteworthy, Termé's collection [along with other three from Turkey cited below, all also from north-eastern part of the distribution area of the species] is peculiar for combining profoundly auriculate stem leaves with relatively broad, oblong-elliptic, distinctly winged and apically notched fruits, i. e., the characters of both $N$. campylophylla and N. pulvinata, thus stressing the above-mentioned problem of delimitation and status of the members of $N$. campylophylla s. 1 . complex. Relevant specimens are: "[B9/B10] Türkey: Prov. Van, Özalp, 2200 m; (metamorpher?) Kalk. 27 V 1966. J. Eiselt" (W 1966-21210, previously identified as Aethionema sp.); "[B9/B10 Ağr1, Doğubayazıt, between Kari and Sheikhbebo]: Turkish Armenia. Bayazet sandzhak. Kare - Bubu, stony slopes. 3 May 1916. B. Shishkin” (LE); “[B9 Ağrı, Doğubayazıt or less likely Diyadin]: Turkish Armenia. Bayazet sandzhak. Bubu - Ipag, stony slopes. 4 May 1916. B. Shishkin" (LE). Specimens collected by B. K. Shishkin (initially annotated as 
Lepidium caespitosum Desv. by him and the second one additionally as "Lepidium sp. nov.?" by P. H. Davis in 1959) are apparently the earliest and northernmost gatherings of $N$. campylophylla. They also appear to be a new record for Ağrı vilayet and the first of them is very likely a novelty for B10 grid square, but the lack of exact locality designation prevents claiming this for sure. The gathering from Özalp can similarly belong to any of B9 or B10 squares. Additional grid square and vilayet record for N. campylophylla s. str. is: "C10 Hakkari, Mor Dag. Mtn steppe, stony ridges screes, crevices, sparse herbage, common, scattered. Alt. 3250 m. 30 June 1967. A. R. Mitchell. Albury, Cheese \& Watson 2994" (K, previously determined as Thlaspi kurdicum and "sp. aff. Thlaspi kurdicum").

\section{Deletions}

\section{Camelina hispida Boiss.}

Uzbekistan: "USSR, Kyzyl-Kum, distr. Buchara (ca 75-80 km occid. ab oppido Buchara), alt. $150 \mathrm{~m}$ s. m., 4 V 1977, leg. Š. Husák" (GZU?).

Based on the cited specimen, this SW Asian (west Irano-Turanian) species has been reported by Mirek (1988) as a novelty for the flora of Uzbekistan and USSR as a whole. This information was not taken into account by subsequent authors (e. g., Czerepanov, 1995; Dorofeyev, 2019) apparently due to omitment because no rebuttal has been hitherto published which is given below.

Unfortunately, a thorough search of the specimen in GZU yielded no result: most likely it was misplaced. At the same time, there are no doubts that it existed and was correctly identified which is supported not only by the authority of Camelina Crantz monographer, but also by a well-drawn illustration made from relevant plant clearly showing C. hispida var. hispida, in full accordance with Mirek's determination.

A fact that the finding is highly unexpected was mentioned by Mirek (1988) himself who stressed that "it lies about $1000 \mathrm{~km}$ to the east to the continuous range of the species" and admitted that it could be of anthropogenic origin. Available facts demonstrate that another explanation is more likely. It was noticed that some specimens of Husák stored in GZU cannot originate from the localities mentioned in their labels and cases of confusion were found. Relevant examples are given below.

1. "URSS, Kara-Kum: Turkmenia, distr. Aschabad (ca $30 \mathrm{~km}$ boreo-occid. ab oppido Aschabad), alt. 80-100 m s. m. 16 IV 1979, leg.
Š. Husák" (GZU000322711). The specimen (originally identified as Chorispora macropoda Trautv.) belongs to Ch. iberica (M. Bieb.) DC. distributed in Caucasus, Trancaucasia and adjacent Iran and Turkey and never recorded from the Middle Asia.

2. "URSS, Azerbaidzhania: Montes Kobistan (ca $60 \mathrm{~km}$ austro-occid. ab oppido Baku), alt. $200 \mathrm{~m}$ s. m. 15 V 1976, leg. Š. Husák" (GZU000322722). This specimen of Parrya khorasanica (Rech. f. et Aellen) D. A. German et Al-Shehbaz (Middle Asia and adjacent Iran and Afghanistan), initially identified as Erysimum sp., is apparently a duplicate of the very similarly looking gathering "URSS, Uzbekistania: Montes Aman-Kutan (Zeravschanskij chrebet) $\quad 60-70 \mathrm{~km}$ austro-occid. ab oppido Samarkand, alt. 700-800 m s. m. 26 IV 1974, leg. Š. Husák" (GZU000322681) originally annotated as Hesperis persica Boiss. Both sheets bear the stamp "Herbar GZU Inv.-Nr. 48-97" proving that they are parts of the same gathering, mislabeled and properly labeled, respectively.

3. "URSS, Tjan-Schan: Uzbekistania, $60-80$ $\mathrm{km}$ bor.-orient. ab oppide Tashkent, prope pagum Čimgan, alt. 1800-2200 m s. m. 2 V 1977, leg. Š. Husák" (GZU000322721, originally identified as Erysimum croceum M. Pop.) is E. cuspidatum (M. Bieb.) DC. not occurring in Middle Asia but common, in particular, in Caucasus. Correctly labeled duplicate bearing the same inventory number 119-82 is "URSS, Caucasus Magnus: Azerbaidzhania (ca 5-8 km bor--occid. ab oppido Pirkuli), alt. 800 m s. m. 24 IV 1979, leg. Š. Husák" (GZU000322737, sub nom. orig. E. substrigosum (Rupr.) N. Busch).

Having these examples in mind, it is obvious that a surprising record of Camelina hispida from Uzbekistan represents similar case and finds its explaination in the label confusion. Occurrence of the species in Middle Asia is not confirmed.

Dontostemon pinnatifidus (Willd.) Al-Shehbaz et H. Ohba

Nepal: "Thinigaon, [Mustang]. Muktinath Himal. 14000 ft. 23 VI 1954. Stainton, Sykes \& Williams 1360" (BM [BM013412062], E [E00959950]).

This gathering is the single basis for the report of $D$. pinnatifidus for Nepal in the most recent treatment (Al-Shehbaz, 2015: 347, with reference to the specimen from BM). Simultaneously, both duplicates were cited under the name $D$. glandulosus (Kar. et Kir.) O. E. Schulz (Al-Shehbaz, 1. c.: 346) and they in fact belong to this species. It appears 
that BM specimen was cited twice, under previous (wrong) and subsequently corrected (though missing on the sheet) determination. In earlier treatment of Al-Shehbaz and Watson (2011), D. pinnatifidus was mentioned for the same and the only Nepalese region, Mustang. In addition to the above gathering, another specimen with relevant identification from that region was found: 'Ghiling, $29^{\circ} 00^{\prime} \mathrm{N}, 83^{\circ} 52^{\prime}$ E, 4000 m. 17. 05. [19]74. J. F. Dobremez, DBR 2992" (E [E00671102]) which is Braya humilis (C. A. Mey.) B. L. Rob. One more collection from Nepal identified as $D$. pinnatifidus has been seen,

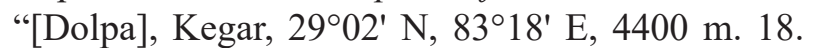
06. [19]61. Jest 135" (E [E00826566])" which is referable to $D$. glandulosus, in full agreement with the data of both Al-Shehbaz and Watson (2011) and Al-Shehbaz (2015) reporting only this species of Dontostemon for relevant region. Taking into consideration the finding of Al-Shehbaz (1. c.: 347) not confirming the presence of $D$. pinnatifidus in Pakistan, it appears that localities in north-eastern part of M Yarlung Zangbo region of Flora of PanHimalaya (Al-Shehbaz, 1. c.: 347) represent southwestern limit of distribution of this species (cf. also Friesen et al., 2016).

Erysimum crassipes Fisch. et C. A. Mey.

Turkmenistan: "Regio transcaspica: Kasandschik [Bereket], in saxosis. VI 1901. P. Sintenis" (C).

Erysimum crassipes, one of the most common SW Asian wallflowers, has not been known from the Middle Asian region before recently when Polatschek (2010) reported it for Turkmenistan based on the single, above-cited specimen. There are no problems with its identification: the plant is unambiguously E. crassipes, as initially annotated (by J. Freyn? J. Bornmüller?) and later (in 2002) confirmed by Polatschek. In contrast, label information is not as unambiguous. First, the gathering is not numbered which is a rare case for P. Sintenis's material collected in 1901. Similarly, quite untypical for this collector is that the gathering is confined to the single specimen (and plant). Third, the species is not included into respective account by Freyn (1903-1906). Fourth, the locality Kasandschik is accompanied throughout the text (Freyn, 1. c.) exclusively with the date 28 IV 1901 and not June 1901. All this in sum combined with the fact that no other collections of $E$. crassipes from Turkmenistan are known, support the suspicion that the label of the discussed specimen is wrong and the species has never been collected from this country and Middle Asia in general.

Noteworthy, the species was also reported by Polatschek (2011) for Georgia based on three gatherings of R. F. Hohenacker from Swant (Zuvand) region, i. e. originating from Talysh (Azerbaijan). This agrees with the fact that E. crassipes is absent in floristic treatments on Georgia (e. g., Khintibidze, 1979; Gagnidze, 2005) and within Caucasus/ Transcaucasia is only known from southern regions of Armenia and Azerbaijan (Dorofeyev, 2012). No material from Georgia has been seen.

Noccaea kurdica (Hedge) Al-Shehbaz: not confirmed to occur in Iraq and presence in Iran requires confirmation (see comment to N. campylophylla above).

Noccaea trinervia (DC.) Steud.: occurrence in Turkmenistan is not confirmed on account of assignment of all relevant collections to $N$. apterocarpa (see comment to the latter speceies above).

Sterigmostemum acanthocarpum (Fisch. et C. A. Mey.) Kuntze

Turkmenistan: "Transcaspian prov., Ashabad distr., Kopet-dagh Mts., Gyaz-dagh Plateau. $11 \mathrm{~V}$ 1912. V. I. Lipsky 4016" (LE).

This is the only gathering based on which $S$. acanthocarpum has been mentioned for Turkmenistan (Jacquemoud, 1988: 112-114). It comprises five duplicates in LE, all determined in 1937 by N. P. Ikonnikov-Galitzky as "Anchonium sterigmoides Lipsky" [nom. nud., = Sterigmostemum ramosissimum (O. E. Schulz) Rech. f.], one of which was annotated by F. Jacquemoud in 1979 as S. ramosissimum. It is clear that a simple technical error is the reason of relevant report. Occurence of $S$. acanthocarpum in Turkmenistan is thus not confirmed and it does not look much probable.

\section{Other noteworthy cases}

Cryptospora omissa Botsch. (C. falcata Kar. et Kir. s. 1.)

[Russia]: "Astrakhan prov., Iskryaninskiy distr., Borovskoy Bugor, Bakhtemir. 30 VII 1951. Sharanina” (LECB, sub nom. "gen. sp.").

Before the present time C. falcata s. 1. has been registered in Russia only in Izhevsk in 1992-1993 as a rare alien plant found in the yard of a fruit/ 
vegetable warehouse (Ilminskikh et al., 1998; Baranova, Puzyrev, 2012) - apparently as an ephemerophyte. The finding in Astrahkan region is clearly of the same status. Unfortunately, lack of ecological information on the label prevents making suggestions on possible way of introduction. Morphologically, the plant, similarly to gatherings from Izhevsk (one specimen seen in LE), corresponds to C. omissa covering the southern part (Middle Asia, Iran, Afghanistan) of C. falcata s. 1. distribution area (Botschantzev, 1963).

Rhammatophyllum pachyrhizum (Kar. et Kir.) O. E. Schulz

"Pr.[ope] Orsk 1852 leg. Antonow" (LE, sub nom. Erysimum sp.).

Quite spacious, though disjunctive area of this most widely distributed species of Rhammatophyllum O. E. Schulz stretches from NW to E Kazakhstan "within $45^{\circ} 30^{\prime}$ and $50^{\circ} \mathrm{N}$ " (Kamelin, 2002: 101). Northernmost locality (mt. Ishkaragantau in ca. $30 \mathrm{~km} \mathrm{SW} \mathrm{Akrab)} \mathrm{stands} \mathrm{about} 15 \mathrm{~km}$ from the border with Russia (Knjasev, 2011) admitting the possibility of finding the species in the latter country. The above label points vicinities of Orsk which in case of old collections may include dozens of kilometers, i. e., can refer to both Russia and Kazakhstan. However, the closest known locality (the above form Ishkaragantau) stands ca. $270 \mathrm{~km}$ apart from Orsk. The only other specimen with similar label seen is that of Megacarpaea megalocarpa (Fisch. ex DC.) Schischk. ex B. Fedtsch. (LE), a species also unknown in neighbourhood of Orsk but occurring much to the south. Hence, actual locality seems to be undetectable. Having in mind the lack of properly documented records of Rh. pachyrhizum from Russia, Kazakhstan appears the only option for the origin of this collection and the species therefore remains endemic to this country.

\section{Acknowledgements}

Curators and responsible managers of the herbaria consulted are profoundly thanked for providing the kind opportunity of treating the collections. Sending the photo of the type of Noccaea iranica by Hamid Moazzeni is highly appreciated as well.

\section{REFERENCES / ЛИТЕРАТУРА}

Akhani H. 2003. Notes on the flora of Iran: 4. Two new records and synopsis of the new data on Iranian Cruciferae since Flora Iranica. Candollea 58(2): 369-385. URL: http://www.ville-ge.ch/cjb/publications/cando582/candollea58-2_369-385.pdf

Al-Shehbaz I. A. 2012. A generic and tribal synopsis of the Brassicaceae (Cruciferae). Taxon 61(5): 931-954. DOI: $10.1002 / \operatorname{tax} .615002$

Al-Shehbaz I. A. 2014. A synopsis of the genus Noccaea (Coluteocarpeae, Brassicaceae). Harvard Pap. Bot. 19(1): 25-51. DOI: 10.3100/hpib.v19iss1.2014.n3

Al-Shehbaz I. A. 2015. Brassicaceae. In: D. Y. Hong (ed.). Flora of Pan-Himalaya. Vol. 30. Cambridge: Cambridge University Press; Beijing: Science Press. Pp. 1-595.

Al-Shehbaz I. A., Watson M. F. 2011. Cruciferae (Brassicaceae). In: M. F. Watson, S. Akiyama, H. Ikeda, C. A. Pendry, K. R. Rajbhandari, K. R. Shrestha (eds). Flora of Nepal. Vol. 3. Edinburgh: Royal Botanic Garden Edinburgh. Pp. 108-181.

Baranova O. G., Puzyrev A. N. 2012. Conspectus florae Provinciae Udmurtiensis (plantae vasculares). Moscow \& Izhevsk: Institute of computer research. 212 pp. [In Russian] (Баранова О. Г., Пузырёв А. Н. Конспект флоры Удмуртской Республики (сосудистые растения). М.-Ижевск: Институт компьютерных исследований, 2012. 212 c.).

Bondarenko O. N. 1974. Torularia O. E. Schulz. In: A. I. Vvedensky (ed.). Conspectus florae Asiae Mediae. Vol. 4. Tashkent: Editio Academiae Scientarum UzSSR. Pp. 56-59. [In Russian] (Бондаренко О. Н. Torularia O. E. Schulz - Чёточник // Определитель растений Средней Азии / Под ред. А. И. Введенского. Т. 4. Ташкент: Изд-во ФАН УЗССР, 1974. С. 56-59).

Botschantzev V. P. 1963. Generis Cryptosporae Kar. et Kir. revisio. Bot. Mater. Gerb. Bot. Inst. Komarova Akad. Nauk SSSR [Notul. Syst. Herb. Inst. Bot. Acad. Sci. URSS] 22: 144-149. [In Russian] (Бочанцев В. П. Обзор рода Cryptospora Kar. et Kir. // Бот. мат. Герб. Бот. ин-та АН СССР, 1963. Т. 22. С. 144-149).

Breckle S.-W., Hedge I. C., Rafiqpoor M. D. 2013. Vascular plants of Afghanistan - an augmented checklist. Bonn: Scientia Bonnensis. 598 pp.

Czerepanov S. K. 1995. Vascular plants of Russia and adjacent states (the former USSR). Cambridge: Cambridge University Press. X+519 pp.

Dorofeyev V. I. 2000. Genus Erucastrum (Brassicaceae) in Caucasian flora. Bot. Zhurn. 85, 7: 183-185. [In Russian] (Дорофеев В. И. Род Erucastrum (Brassicaceae) во флоре Кавказа // Бот. журн., 2000. Т. 85, № 7. С. 183-185). 
Dorofeyev V. I. 2012. Brassicaceae Burnett, nom. cons., nom. alt. (Cruciferae Juss., nom. cons.). In: A. L. Takhtajan (ed.). Conspectus florae Caucasi. Vol. 3(2). St. Petersburg \& Moscow: KMK Scientific Press. Pp. 371-469. [In Russian] (Дорофеев В. И. Brassicaceae Burnett, nom. cons., nom. alt. (Cruciferae Juss., nom. cons.) // Конспект флоры Кавказа / Под ред. А. Л. Тахтаджяна. Т. 3(2). СПб.-М.: Товарищество научных изданий КМК, 2012. C. 371-469).

Dorofeyev V. I. 2019. Camelina (Cruciferae, Brassicaceae): structure of genus and list of species. Vavilovia 2, 2 : 3-24. [In Russian] (Дорофеев В. И. Рыжик - Camelina (Cruciferae, Brassicaceae): внутриродовая структура и видовой состав // Vavilovia, 2019. Т. 2, № 2. C. 3-24). DOI: 10.30901/2658-3860-2019-2-3-24

Fakhr Ranjberi H. 2017. Noccaea Moench. In: Assadi M., Sajedi S., Maassoumii A. A. (eds). Flora of Iran. Vol. 143 (Brassicaceae). Tehran: RIFR. Pp. 137-161. [In Persian]

Freyn J. 1903-1906. Plantae ex Asia Media. Bull. Herb. Boissier, sér 2, 3: 557-572, 685-700, 857-872, 10531068; 4: 33-48, 443-458, 755-770, 1105-1128; 5: 557-572, 784-799, 1012-1027; 6: 193-216.

Friesen N., German D. A., Hurka H., Herden T., Oyuntsetseg B., Neuffer B. 2016. Dated phylogenies and historical biogeography of Dontostemon and Clausia (Brassicaceae) mirror the palaeogeographic history of the Eurasian steppe. J. Biogeogr. 43(4): 738-749. DOI: 10.1111/jbi.12658

Gagnidze R. 2005. Vascular plants of Georgia. A nomenclatural checklist. Tbilisi. 248 pp.

German D. A. 2005. Two new combinations in the Caucasian Cruciferae. Turczaninowia 8, 2: 20-21. [In Russian] (Герман Д. А. Две новые комбинации в кавказских крестоцветных (Cruciferae) // Turczaninowia, 2005. Т. 8, № 2. C. 20-21). URL: http://old.ssbg.asu.ru/turcz/turcz205-20-21.pdf

German D. A. 2015. Cruciferae (Brassicaceae): Alternative treatment for the "Conspectus of the vascular plants of Mongolia". Turczaninowia 18, 2: 39-67. DOI: 10.14258/turczaninowia.18.2.4

German D. A., Chen W.-L. 2009. Notes on the family Brassicaceae in China. J. Syst. Evol. 47(3): 202-219. DOI: 10.1111/j.1759-6831.2009.00022.x

Hedge I. C. 1968. Lepidieae. In: K. H. Rechinger (ed.). Flora Iranica. Vol. 57. Graz: Akademische Druck- u. Verlagsanstalt. Pp. 63-122.

Hedge I. C., Lamond J. M. 1980. Lepidieae. In: C. C. Townsend, E. Guest (eds). Flora of Iraq. Vol. 4(2). Baghdad: Ministry of Agriculture \& Agrarian Reform. Pp. 885-932.

Ilminskikh N. G., Baranova O. G., Puzyrev A. N. 1998. Conspectus of the flora of Izhevsk and its vicinities. In: V. V. Tuganaev (ed.). Priroda Izhevska i ego okrestnostě [The nature of Izhevsk and its vicinities]. Izhevsk: Udmurtiya. Pp. 81-169. [In Russian] (Ильминских Н. Г., Баранова О. Г., Пузырёв А. Н. Конспект флоры г. Ижевска и его окрестностей // Природа Ижевска и его окрестностей / Под ред. В. В. Туганаева. Ижевск: Удмуртия, 1998. C. 81-169). URL: https://elibrary.unatlib.ru/handle/123456789/25087

Jacquemoud F. 1988. Monographie du genre Sterigmostemum M. Bieb. (Cruciferae - Hesperideae). Boissiera 40: 5-161.

Jafri S. M. H. 1973. Brassicaceae. In: E. Nasir, S. I. Ali (eds). Flora of West Pakistan. Vol. 55. Karachi: Ferozsons. Pp. 1-308.

Kamelin R. V. 2002. Notes on Cruciferae of Asia. Genus Rhammatophyllum and its affinity. Bot. Zhurn. 87, 12: 97-109. [In Russian] (Камелин Р. В. Заметки о крестоцветных (Cruciferae) Азии. Род Rhammatophyllum и его родство // Бот. журн., 2002. Т. 87, № 12. С. 97-109).

Khintibidze L. S. 1979. Erysimum (Tourn.) L. In: Sh. I. Kutateladze (ed.). Flora of Georgia. Ed. 2. Vol. 5. Tbilisi: Metsniereba. Pp. 36-50. [In Georgian]

Khosravi A. R., Jacquemoud F., Mohsenzadeh S., Menke M., Mummenhoff K. 2009. Phylogenetic position and taxonomic classification of Aethionema trinervium (Brassicaceae): a morphologically variable subshrub from southwestern Asia. Ann. Missouri Bot. Gard. 96(4): 564-574. DOI: 10.3417/2007004

Knjasev M. S. 2011. Notes on some species of Brassicaceae in Urals and adjacent territories. Novosti Sist. Vyssh. Rast. [Novit. Syst. Pl. Vasc.] 42: 136-146. [In Russian] (Князев M. C. Заметки о некоторых видах крестоцветных (Brassicaceae) на Урале и сопредельных территориях // Новости сист. высш. раст., 2011. Т. 42. С. 136-146).

Lazkov G. A., Sultanova B. A. 2014. Kadastr flory Kyrgyzstana. Sosudistyye rasteniya [Checklist of vascular plants of Kyrgyzstan]. Bishkek: National Academy of Sciences of Kyrgyz Republic. 126 pp. [In Russian] (Лазьков $\boldsymbol{\Gamma}$. A., Султанова Б. $\boldsymbol{A}$. Кадастр флоры Кыргызстана. Сосудистые растения. Бишкек: НАН КР, 2014. 126 с.).

Meyer F. K. 2006. Kritische Revision der "Thlaspi"-Arten Europas, Afrikas und Vorderasiens. XI. Vania F. K. Mey. Haussknechtia 11: 217-228.

Mirek Z. 1988. Camelina hispida Boiss. - a new species in the flora of USSR. Fragm. Florist. Geobot. 31-32 (3-4): 305-308.

Mozaffarian V. 1996. Studies on the flora of Iran, new species, new combinations and new records. Iranian J. Bot. 7(1): 127-142.

Nikitin V. V., Geldikhanov A. M. 1988. Opredelitel rastenǐ̌ Turkmenistana [Key for plants of Turkmenistan]. Leningrad: Nauka. 680 pp. [In Russian] (Никитин В. В., Гельдиханов А. М. Определитель растений Туркменистана. Л.: Наука, 1988. 680 с.). 
Nowak A., Nobis M. (eds) 2020. Illustrated flora of Tajikistan and adjacent areas. Warsaw, Cracow, Opole: Polish Academy of Sciences. Botanical Garden Center for Biological Diversity Conservation \& Polish Botanical Society. 766 pp.

Pachomova M. G. 1974. Cryptospora Kar. et Kir. In: A. I. Vvedensky (ed.). Conspectus florae Asiae Mediae. Vol. 4. Tashkent: Editio Academiae Scientarum UzSSR. Pp. 136-137. [In Russian] (Пахомова М. Г. Cryptospora Kar. et Kir. - Скрытосемянница // Определитель растений Средней Азии / Под ред. А. И. Введенского. Т. 4. Ташкент: Изд-во «ФАН» УзССР, 1974. С. 136-137).

Polatschek A. 2010. Revision der Gattung Erysimum (Cruciferae): Teil 1: Russland, die Nachfolgestaaten der USSR (excl. Georgien, Armenien, Azerbaidzan), China, Indien, Pakistan, Japan und Korea. Ann. Naturhist. Mus. Wien, B 111: 181-275.

Polatschek A. 2011. Revision der Gattung Erysimum (Cruciferae), Teil 2: Georgien, Armenien, Azerbaidzan, Türkei, Syrien, Libanon, Israel, Jordanien, Irak, Iran, Afghanistan. Ann. Naturhist. Mus. Wien, B 112: 369-497.

POWO [2021] Plants of the World online. URL: http://www.plantsoftheworldonline.org/ (Accessed 16 March 2021).

RBGE [2021] Royal Botanic Garden Edinburgh herbarium catalogue. URL: https://data.rbge.org.uk/search/herbarium/ (Accessed 20 March 2021).

Rechinger K. H. 1951. Cruciferae iranicae novae vel minus cognitae. Phyton (Horn) 3(1-2): 44-68.

Virtual Herbaria [2021] URL: http://herbarium.univie.ac.at/database/search.php (Accessed 20 March 2021).

Yunusov S. Yu. 1978. Cryptospora Kar. et Kir. In: P. N. Ovczinnikov (ed.). Flora Tadzhikskou SSR [Flora of Tajik SSR]. Vol. 5. Leningrad: Nauka. Pp. 139-142. [In Russian] (Юнусов С. Ю. Скрытосемянница - Cryptospora Kar. et Kir. // Флора Таджикской ССР. Под ред. П. Н. Овчинникова. Т. 5. Л.: Наука, 1978. С. 139-142).

Zhou T.-Y., Lu L.-L., Yang G., Al-Shehbaz I. A. 2001. Brassicaceae (Cruciferae). In: Z.-G. Wu, P. H. Raven (eds). Flora of China. Vol. 8 (Brassicaceae through Saxifragaceae). Beijing: Science Press; St. Louis: Missouri Botanical Garden Press. Pp. 1-193.

Zohary M., Heyn C. C., Heller D. 1980. Conspectus florae orientalis. An annotated catalogue of the flora of the Middle East. Vol. 1. Jerusalem: The Israel Academy of Sciences and Humanities. 107 pp. 